(3) Le nombre moyen des positions pour une paire prise $(3 \cdot 0)$;

(4) Le nombre des planètes connues observées;

(5) Le nombre des planètes nouvelles découvertes;

(6) Le rapport du nombre des planètes nouvelles au nombre des connues (0.I4);

(7) La grandeur stellaire moyenne des nouvelles (13.3).

Les tables suivantes éclairent le rôle de l'observatoire de Siméis dans le service international des petites planètes. La table II donne la répartition de toutes les nouvelles planetes découvertes depuis le $I$ janvier I9I2 jusqu'au I juillet I933 d'après les années et les différents observatoires ( $45^{8}$ pour Siméis). La table III présente les mêmes données, mais seulement pour les nouvelles munies d'orbites et ayant reçu de numéros (93 pour Siméis). La table IV présente les données sommaires et le rapport du nombre des planètes numérotées à toutes les nouvelles découvertes à l'observatoire susdit pendant la période envisagée.

L'examen de ces données permet d'arriver à des conclusions suivantes:

(I) Le service des petites planètes est choisi très heureusement pour Siméis conformément à l'instrument et à la situation de l'observatoire.

(2) Cette circonstance de même que l'organisation appropriée du travail et surtout son exécution méthodique pendant une longue série d'années ont permis à Siméis d'accomplir près de $\frac{1}{f}$ du travail d'observation photographique des petites planètes exécuté pendant la durée de son activité et de prendre dans ce domaine la deuxième place parmi les observatoires du monde entier. Il est indispensable de noter que l'astrographe à 5 pouces de Siméis est de beaucoup plus faible que tous les instruments chargés de ce travail dans les autres observatoires.

(3) Depuis le commencement du travail jusqu'au I juillet I933 il a été découvert à Siméis $45^{8}$ planètes nouvelles dont 93 reçurent les éléments certains et entrèrent dans la liste des planètes numérotées.

(4) Il faut constater que le défaut du service des petites planètes à Siméis est comparativement le petit nombre des planètes numérotées, nombre qui aurait pu être augmenté par l'organisation appropriée des calculs rapides des orbites approchées et des éphémérides pour les planètes nouvelles découvertes.

Plus loin le service des petites planètes à Siméis est examiné relativement à son développement historique dans le courant de 22 ans et sont évaluées ses possibilités en connexion avec le changement des objets et des méthodes de recherches.

\title{
COMMISSION 22. (METEORS.)
}

\author{
Acting Président: Mr Felix de Roy. \\ Secretary: Mme G. Camille Flammarion.
}

The Commission first took up the question of the inclusion in their subjects of the Zodiacal Light and related phenomena, and in particular the brightness of the night sky, which had been referred to them by the General Assembly. After some discussion, the following resolution, proposed by the acting President, and seconded by Dr Bosler, was adopted:

I. While, in conformity with the motion voted by them at the Harvard Meeting (Transactions, 4, p. 245), this Commission still consider that it is not desirable that Comets should be added to their subjects, they suggest that, since several of their 
members, active in the field of meteors, are also working on the problem of Zodiacal Light, the latter subject, and related phenomena, might be handled by a SubCommittee of Commission 22.

Another motion was voted in the following terms, and referred to the General Assembly:

2. The Commission again most respectfully urge upon the Government of France the great importance of the prompt rediscovery and study of the Chinguetti (Adrar) meteorite, and upon the Government of the Union of Soviet Socialist Republics the importance of further study of the great Siberian fall of I908. They express regret that no recent work has been done at Meteor Crater, Arizona, and they think it highly desirable that the exploration there be completed.

With respect to the Chinguetti meteorite, Dr Bosler said that, according to the latest information, the best means of locating the mass, under the peculiar circumstances prevailing in the Adrar, would be to entrust this task to a cultivated Arab, knowing the region well. The chief difficulty for the present seems to be in the choice of such a local investigator. Although there might be some doubt as to the meteoric character of the Chinguetti mass, the matter was well worth following up.

The draft Report was then discussed in detail, and finally adopted with some minor alterations and additions. Doubt having been expressed as to some of the new limitations proposed for the definition of a "radiant", it was agreed to drop the matter, pending further discussion by private correspondence.

The following recommendations were adopted unanimously:

3. It is desirable that gnomonic maps should be made available, which will cover a larger area of the sky than those now in use, and will include all stars down to magnitude $6 \cdot 0$. In this connection, attention is called to the desirability of obtaining publication of the maps planned by $\mathrm{T}$. W. Backhouse.

4. It is recommended that in future publications of the details of observations:

(a) Studies of hourly rates should always include the magnitude of the faintest stars visible in the zenith, together with a statement as to the conditions regarding the extent of the field of view.

(b) Lists of radiants should be accompanied by details of the watches in which the same were determined.

(c) Such details should include, not only the number of meteors counted, but also the number of those mapped.

It is desirable that:

(d) Lists of radiants should include the diameter of the area of the corrected radiant.

5. It is important to determine if the metallic dust which is present in the atmosphere, and can be isolated by a magnet, is of meteoric origin. This dust can easily be collected by simple methods. Simultaneous observations of this dust, in different regions, could eventually establish a correlation between the number of metallic particles collected, and periods of meteoric activity. If a sufficient quantity of the dust could be collected, it might be submitted to chemical analysis.

The following papers were submitted to the meeting and read wholly or in part:

I. Prof. Dr J. Svoboda: Expériences sur un météore artificiel.

2. Dr V. Guth: Un nouveau réticule pour l'observation des météores.

3. G. Camille Flammarion et G. Arend: Détermination du radiant de l'essaim des étoiles filantes du 9 octobre I933, basée sur une plaque photographique prise à l'Observatoire de Juvisy. 
4. E. Vandekerkhove: Essai de détermination du radiant apparent d'un essaim d'étoiles filantes à l'aide de documents photographiques.

5. Dr C. Hoffmeister: Report on recent Meteor Work at Sonneberg, Germany.

6. I. Astapowitsch: A project of Standard Notations in Meteoric Astronomy.

\title{
COMMISSION 23. (CARTE DU CIEL.)
}

\author{
President: M. E. Esclangon. \\ Secretary: M. E. PaIoQue.
}

M. le Président rend hommage à ceux de ses membres que la Commission a perdus depuis sa précédente réunion: son vénérable et éminent Président d'honneur Benjamin Baillaud, premier Président de l'Union; et Monsieur Gonnessiat qui fut Directeur de l'Observatoire d'Alger.

Il souhaite la bienvenue aux membres nouveaux: MM. Donner, Furuhjelm, Nangle, Paloque, H. H. Plaskett, Stein.

Il expose l'état d'avancement du Catalogue et de la Carte, fait ressortir que, malgré les progrès réalisés depuis la réunion de Cambridge, il reste encore beaucoup à faire et insiste sur l'importance qui s'attache à l'achèvement des travaux dans les délais les plus réduits.

En ce qui concerne le Catalogue en coordonnées rectilignes, qui est la partie la plus avancée, il examine successivement la situation pour quelques zones qui se heurtent à des difficultés.

La zone $+39^{\circ}$ à $+32^{\circ}$, abandonnée par Potsdam, a été en partie reprise par Oxford $\left(33^{\circ}\right.$ et $\left.32^{\circ}\right)$ et Hyderabad $\left(39^{\circ}\right.$ à $\left.36^{\circ}\right)$. Il reste les zones $35^{\circ}$ et $34^{\circ}$ qui demeurent sans titulaire. Qui consentira à en prendre la charge? A cette question, M. Stroobant a déjà répondu que l'Observatoire de Uccle serait disposé à l'accepter. M. le Président remercie M. Stroobant de cette offre généreuse qui vient s'ajouter à l'antérieure prise en charge de toute la Carte de la zone de Potsdam. Il l'accepte au nom de la Commission, sous réserve, cependant, d'accorder la priorité aux observatoires d'Oxford et de Hyderabad, au cas ou ils désireraient combler euxmêmes cette lacune qui sépare leur lots respectifs.

Pour les zones $-38^{\circ}$ à $-40^{\circ}$, les clichés ont été pris à Perth, l'Observatoire d'Edinburgh s'est chargé des mesures et des calculs. M. Sampson, n'ayant pu publier les résultats, malgré une subvention accordée par l'Union, suggère que l'Union se charge elle-même de cette publication. M. le Président se demande, puisque en définitive il s'agit des zones de Perth, si ce dernier Observatoire ne pourrait pas lui-même procéder à cette publication, en bénéficiant de la subvention consentie dans ce but à l'Observatoire d'Edinburgh. Mais M. Bemporad, d'accord avec M. Bianchi, propose que la publication soit faite à Catane, ou les frais d'impression sont peu élevés; la correction des épreuves pourrait même être effectuée sur place. M. le Président prend acte de cette offre susceptible de résoudre avantageusement la difficulté et, aux applaudissements de l'assistance, il adresse de chaleureux remerciements à MM. Bemporad et Bianchi.

Incidemment, M. Bemporad dit qu'il fait des recherches tendant à l'unification des grandeurs stellaires du Catalogue photographique, et qu'il espère arriver à une solution simple et pratique de ce difficile problème. La Commission l'encourage à poursuivre cette importante étude. 